\title{
Study on Construction of Domestic College Sports Network Teaching
}

\section{Platform}

\author{
Shuaicheng Luo ${ }^{1}$, Ying Wang ${ }^{1}$ \\ ${ }^{1}$ Sports Department, Nanchang Institute of Science and Technology, Nanchang Jiangxi, 330108 \\ 346591653@163.com
}

KEYWORDS: Teaching Methods; Teaching Efficiency; Teaching System

\begin{abstract}
With the development of society, the education sector is also beginning to change, the current science and technology into classroom education were to improve the quality of teaching in the classroom, in addition to physical education among the general exercise of outdoor sports, there are physical training and sports culture like education, classrooms were added in modern instructional videos, to establish a new network teaching platform. Improve curriculum design is simple, small open face problems so that the classroom can be connected by a network teaching platform construction courses, increase exchanges among universities, the sharing of resources, while allowing students to self-study, to actively join in the classroom, this article will Thinking discussed from domestic college sports network teaching platform construction.
\end{abstract}

\section{Introduction}

In recent years, with the development of the network, more and more students began to like to find the information they need in this large network of resources, in addition to entertainment and comedy which network resources, also joined the teaching video tutorial courses, teaching resource sharing, all through the network platform, which provides for the university teachers a lot of different teaching methods, in order to enrich their teaching and make it richer while forming a single case of their own teaching style. While teachers for software applications is not particularly skilled, but with some simple teaching software, although the network teaching foundation, but teaching them that the network, which is not enough. In the information technology developed modern society, building a network teaching platform, enables university teachers to update the original concept of the old teaching, improve teaching quality, and can stimulate students 'innovative spirit, and enhance students' practical ability. According to the status of network teaching analysis, some bad information network will mislead students, so that the need to regulate the country, can improve network teaching environment. Therefore, network teaching in the classroom will set off a new wave of education, I hope this article can make use of its application in the classroom were analyzed and found to improve the efficiency of classroom teaching methods and ways to improve online teaching.

\section{Status of Domestic Network Teaching}

As shown in Table 1 below, the student's active time is spent in the network, lack of proper exercise time, which is also from the side reflects the application of the network is a lot, every day there are about four hours or so. Present students with computer access than students to use the 
mobile Internet more, they often use mobile phones access the Internet. Students in the Internet world, more leisure, for example, chat, tweeting and watching the news, and did not become a major learning activities of students. Although the Internet has a vast space for learning can improve learning efficiency of learning and comprehensive learning resources, but these resources did not attract the majority of students, resulting in a waste of resources, it can not be fully utilized, reflect its value. The main reason is: the current classroom education, so that students are used to receiving, rather than independent thinking, lack of after-school assignments bootable, can not open students' thinking; it also makes a wrong judgment that most students will learning can be positioned in the final results to the extent that you can and just over the line. These students will not lead to the use of resources, interest in learning is not high, lack of initiative to explore the power of knowledge. This is the drawback of the domestic network holds many lessons for teaching.

And it also has many advantages, incoming network teaching, led to the transfer of information in the world, in addition, there is a multimedia platform connected, it changed the original single assessment of ways to make physical education performance evaluation method becomes diverse. Some colleges and universities also this special construction QQ group, QQ group in addition to this to provide students with independent learning platform, but also so that resources become more targeted, so that the original 'big resources' into a 'small resource' easier students use. With the QQ group, the students and teachers can communicate better, and then come to class with questions, enhance the interaction between teachers and students' classroom, while expanding their knowledge of the sport. With the advent of education reform, school PE teachers more actively support the use of the Internet assisted teaching, to provide the necessary facilities and equipment to improve teaching quality of teachers in teaching classes, selectively produced videos to enhance the usefulness of information.

Table 1 The time spending

\begin{tabular}{|l|l|l|l|l|l|l|}
\hline \multirow{2}{*}{ Method } & \multicolumn{6}{|l|}{ Time } \\
\cline { 2 - 7 } & $1-2$ & $3-4$ & $5-6$ & $7-8$ & $9-12$ & $>12$ \\
\hline Mobile Network & 76 & 161 & 0 & 0 & 0 & 6 \\
\hline & 188 & 49 & 6 & 0 & 0 & 0 \\
\hline Content & Talking & Wechat & News & Study & Game & Viedo \\
\hline & 32 & 17.2 & 18 & 8.2 & 10.7 & 13.5 \\
\hline
\end{tabular}

\section{The Method to Build Sports Network Teaching Platform of Domestic Colleges}

First, colleges and universities to set up in the school sports website which will be carefully selected teachers teaching programs, sports programs, subjects, objectives and tasks of teaching each semester on the platform on display. And it placed sports experts, professors, coaches, referees, instructors and other information in the site. This allows students to keep abreast of information about sports teaching; according to their own preferences, using the campus network platform, select the item you want to learn. This platform helps to develop students' personality, as well as teachers and school staff and students to provide a learning and communication platform, in this platform, students can express their views, but the views can be accepted for teachers to improve their teaching lesson form, and can learn from each other between the field of teaching, students and teachers, progress. 
Second, the evaluation system was added in the Sports Network teaching platform, rich evaluation methods. College physical education before, too much emphasis on the end result, which makes many students can not play to their strengths, and teachers also ignore the students for the final exam standards and pay hard, but often this process is the students' growth and progress witness. So after adding an evaluation system, increase the students' feedback, teachers from students in the mirror to see their own shortcomings and advantages, you can better manage the classroom, both the balance of time and play a maximum value of classroom time. Sometimes evaluated to record details of the teacher in class, teach the whole process of evaluation, a guide for teachers.

Evaluation of Education is not just for the evaluation of teachers, but also allows students to self-evaluate the performance of this semester, team cooperation between the team evaluation, evaluation of class solidarity between the collective and other diversified evaluation methods, and teachers for students evaluation is to provide students with a guide, it is to increase communication between teachers and students, and cooperation. This teaching approach helps improve teaching efficiency and improve classroom results. In this platform also reduces the workload of teachers, all the results are electronic files, paper registration is not necessary for teachers and students in colleges and universities need to port login, after evaluation of the classroom, you can check the score.

Third, pay attention to students 'comprehensive ability and overall physical condition, this sport will become a scientific discipline, in particular, diversification, students of different ability to change students' learning attitudes. This requires PE teachers in addition to professional knowledge, should also change their approach to teach the online teaching into the classroom into. After teachers and other colleges and universities to learn, teachers can find the most suitable teaching methods, enhance self-worth. So students can fully develop in the sport class, in addition to exercise, physical fitness, but also can improve their temperament, their ability to cultivate self-learning.

\section{Conclusion}

In general, China now college sports network teaching platform is still in its infancy, the first time since China's entry into the information age is not long, the degree of control over the network of teachers is not strong, it sports a number of experienced teachers, advanced age, cognitive ability of the network is not strong, we can not accept new kind of education. Second, online teaching of open education area has regional characteristics, only a few colleges and universities offer online courses teaching. The student's acceptance is different, and the response to various areas of good and bad. Thirdly, contemporary network teaching platform without a better teaching environment, teachers are not well trained. Fourth, college sports teachers were bound by the traditional teaching and there is no change educational concept, the idea of imprisonment, affecting the development of online teaching. The teacher's network technology level is not high enough. Fourth, the extent of PE teacher education is not high, we do not have a specific teaching program management, lack of order of classroom teaching. Fifth, for students in PE class requirements gradually increased, while universities can not meet the increasing requirements of teaching students, the availability of equipment and very little equipment.

Therefore, if you want to change the status quo bad, we should start with the construction of the network teaching platform started, with the support of the state, as well as monitoring of school leadership, regulation of this situation, and for teachers are set up for specific courses improve the quality of teachers, improve teaching quality, to meet the various needs of their students. 


\section{REFERENCE:}

[1] He Wenqing. College Sports Network Teaching Platform Construction Status analysis [J]. Education and Vocation, 2013,09: 166-167.

[2] Wang Jianwen. Development Status, Guangdong Private Colleges and Universities Sports department website analysis [J]. movement, 2012,07: 74-75.

[3] Wang Kaishou. Sports Network Teaching Situation and Development Strategy of Higher Education Research [J]. Chengdu Institute of Physical Education, 2006,04: 121-124.

[4] Zhu Jianqing. Configuration choices College Resource Structure and Optimization cluster level [J]. China Sports Science, 2006,06: 104-111.

[5] Li Shujuan. and modern network multimedia teaching in university sports [J]. Liaoning University of Science and Technology, 2013,06: 648-652. 